\title{
ПОЛЬСЬКА ШКОЛА ЛІТЕРАТУРИ ФАКТУ: ГЕРОЇ РЕПОРТАЖІВ ЯК ДЗЕРКАЛО ДІЙСНОСТІ
}

\author{
Христина Головко \\ Львівський національний університет імені Івана Франка \\ вул. Генерала Чупринки, 49, 79044, Львів, Україна \\ e-mail: khristinagolovko@gmail.com \\ https://orcid.org/0000-0001-7603-984X
}

У статті проаналізовано ключову особливість польської школи літератури факту, а саме журналістську роботу із героями матеріалів, які є основою репортерського тексту. Досліджено методологію та характерні для польського репортажу особливості добору героїв. Розглянуто специфіку комунікативних стратегій польських репортерів, репортерські прийоми. Для кращого розуміння наведено приклади із репортерських текстів.

Ключові слова: нова журналістика, польська література факту, комунікативна стратегія, метод «live-in».

Постановка проблеми. Літературна журналістика, або ж «нова журналістика», зародилась у США у 60-ті роки ХХ століття, за часів індустріальних, соціально-політичних змін, швидко стала популярною серед читачів, набула нових форм та різновидів і поширилась за межі країни. Однією з найпопулярніших шкіл літературного журналізму вважається польська школа «літератури факту», яка розвивалася окремо від англо-американської. Згідно з польським «Словником літературних жанрів», репортаж - це «жанр на межі» публіцистики, наукової літератури та художньої літератури. Сформований у другій половині дев'ятнадцятого століття, якому притаманний динамічний розвиток преси. На цей період припали роботи з історичним описом подій, очевидцем яких був і сам автор»1.

Польська школа художнього репортажу за часи свого існування викристалізувала свої унікальні жанрові особливості, серед яких найзнаковішою є робота 3 героями репортажів.

Аналіз останніх досліджень та публікацій. Серед закордонних науковців варто згадати Е. Денніса, М. Вайнгартена, Н. Сімса, М. Крамера, Ш. Ф. Фішкіна, Б. Лонсберрі, Н. Міллза. Щодо українських науковців, то дослідженням «нового журналізму» та польського репортажу займаються М. Титаренко, Т. Лильо, М. Шутяк, Л. Белей, О. Шеремет, Є. Федишин, Г. Стембковська.

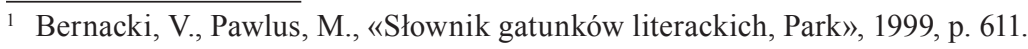

(C) Головко Х., 2020

Наукове керівництво, редагування і рекомендація до друку - доц. Лильо Т. Я. 
Виклад основного матеріалу дослідження.

Однією із ключових особливостей цієї школи є те, що репортери завдяки жанру літературного репортажу розповідали звичайні людські історії, ілюстрували справжнє, щоденне, життя. «Ми показували реалії життя, як люди живуть, працюють, як їх лікують, в яких умовах вони їздть на роботу. Ці деталі, передані гарною мовою й укладені у відповідну форму, змушували читача робити висновки» ${ }^{2}$.

Репортери знаходили унікальних, ілюстративних та метафоричних героїв, чия історія була віддзеркаленням часу, проблеми, ситуації. Важливо заакцентувати, що польські репортери показували об'єктивну реальність, засновану на фактах. Тому герої у польському репортажі відіграють роль прототипів, у житті яких відображається дійсність. Вони краще пояснюють читачеві картину ситуації, дають змогу відчути спорідненість, близькість ситуації. «Герой - це найсвятіше для репортера, журналіста. Він віддає своє життя в твої руки і ти відповідаєш за це життя. Ти навіть маєш більше думати про нього, аніж він сам»³.

Герої польського репортажу. Польський літературний репортаж робить історію людини (людей) основним ядром тексту. Про це говорить відомий польський репортер Вітольд Шабловський: «Для мене в центрі репортажу завжди люди. А події - це ж не якісь абстракції, що висять в повітрі, їх теж творять люди. За подіями завжди стоять люди, їхні емоції, відвага, ідеї, принципи»

Героєм репортажу може стати будь-яка людина, у життєвій ситуації якої подія, явище, тенденція, відображається найглибше, найяскравіше. Найчастіше журналісти полюбляють обирати героєм звичайних людей з незвичайними історіями, щоб репортаж був близьким читачеві. Журналіст має знайти саме тих, ексклюзивних героїв, які, безсумнівно, відіграють у репортажі одну із найважливіших ролей. Це мають бути реальні рельєфні документальні герої, які «говорять» у тексті своїми голосами, а не «голосом» автора, зі своїми звичками, вадами, характерами, із влучною деталізацією. Адже «немає такої сфери (соціум, наука, економіка, політика), яку неможливо розкрити через ті чи інші долі, особистості, персонажі», - підтверджує медіадослідниця Вікторія Бабенко .

Здебільшого герої прикріплені до тематики, проблематики, спеціалізації репортера, що дає змогу репортеру детально дослідити конкретну тему, яка його цікавить. Польські репортери зосереджуються на конкретних проблемах чи регіонах, часто стаючи визнаними експертами: Войцех Ягельский - щодо Африки, Павел Смоленський - щодо Ізраїлю та Палестини, Маріуш Щигел - щодо Чехії. Яцек Гуго-Бадер та Кристина Курчаб-Редліх - Росії, Войцех Тохман - щодо близького Сходу та воєнних конфліктів, як і зрештою Павел Решка, Пьотр Ібрагім Кальвас - експерт у справах

2 Bartosz, M., (2010), Małgorzata Szejnert, [online: October, 2010], available at: https://culture.pl/ru/ artist/malgozhata-sheynert

3 Shcheglova, J., (2012), Report as a translation from reality, online: March 22, 2012], available at: https:// zik.ua/news/2012/03/22/reportazh_yak_pereklad_z_realnosti_340279

4 Kostovskaya, A., (2016), «Witold Shablovsky: I want «Righteous Traitors. Neighbors from Volyn» to become a bridge between the Poles and the Ukrainians», [online: December 16, 2016], available at: http://archive.chytomo.com/interview/vitold-shablovskij-xochu-shhob-pravedni-zradniki-susidi-zvolini-stala-mostom-mizh-polyakami-j-ukraiincyami

5 Babenko, V., (2013), Narrative text in the news format, [online], available at: http://er.ucu.edu.ua/ handle/1/711 - pp. 268. 
Єгипту, Земовіт Щерек, Пьотр Андрусечко, Катажина Квятковська-Москалевич пишуть про Україну та ін.

До прикладу, Яцек Гуго-Бадер у своїй книзі «Біла гарячка» історія за історію розповідає про життя представників «соціального дна»: безхатьків, алкоголіків, нарко- та алкозалежних людей, намагаючись відчути і зрозуміти їхнє життя таким, яким воно є. Адже, на думку репортера, такі історії дають зрозуміти глобальність явищ. «Пишу про бідність, про бездомних. Думаю, що загалом різниці немає. Світ вигнанців, злочинців, проституток, наркоманів, алкоголіків... у цих країнах не надто різниться $\rangle^{6}$.

Рідше репортери пишуть про політиків чи інтелігенцію будь-якої сфери, бо їхнє життя перебуває на деякій відстані. Вибір героїв залежить від типу репортажу. Ось політичний літературний репортаж, навпаки, смакує пікантними подробицями 3 життя відомих політиків і шукає в цих персонажах усе найцікавіше, аби відкрити читачеві ще щось, невідоме раніше. Тут варто згадати влучний репортаж Павла Решки про Дональда Туска - колишнього прем'єр-міністра Польщі. Попри медіакомпанію політика та його «пластмасовий образ», Решці вдалося показати Туска справжнім - під час гри у футбол із своїми співробітниками та двома колишніми гравцями національної збірної з футболу, які подавали м'яч можновладцю, але не мали права його вдарити, лише помічнику Туска було дозволено забивати голи. Проте, коли репортери через три дні знов прийшли на гру, їх впізнали і на полі запанувала ідилія, яку Туск разом із командою пропагував у передвиборчій кампанії, ось це й потрібно було для репортажу, щоб показати справжню історію політика, переконаний Решка: «Ось ці дві картинки, потрібні для репортажу: справжнього Туска та ілюзії, яку він створює для ЗМІ. Це був удар - відтоді Туск відмовляється зі мною говорити» .

Натомість соціальний репортаж тяжіє до розповіді про звичайних людей з незвичайними історіями. Польський репортер, автор книг «Готланд», «Зроби собі рай», Маріуш Щигел, один із журналістів молодого покоління польської «літератури факту», що гуртувалася навколо «Gazeta Wyborcza» (до цього покоління належать Кристина Курчаб-Редліх, Яцек Гуго-Бадер, Маріуш Щигел, Войцєх Тохман $\left.{ }^{8}\right)$, у своїх репортажах завше акцентує на людині: «У репортажі для нас, передовсім, найважливіша людина. Чимало інших жанрів, навіть художньої літератури, описують людину, але в репортажі ми намагаємося її зрозуміти. Не докопуватися, не дошукуватися до всіх особистих подробиць, які вона, можливо, бажає залишити при собі, а просто зрозуміти»9.

Зрозуміти людину і розповісти світові іiї історію, в якій світ побачить відображення створеної і облаштованої людиною дійсності та як сама дійсність стає лю-

${ }^{6}$ Baley, L., (2012), «A journey through the depths of souls: the author of «White Fever» on the specific features of the post-Soviet space», [online: May 8, 2012], available at http:/tyzhden.ua/ Culture/43125?attempt $=1$

7 Kovalenko, O., Golovko, K., (2014), Reporting rules by Pawel Reszka: «In front of Putin's apartment I saw Putin's Russia», [online: October 28, 2014], available at: https://ms.detector.media/mediaprosvita/ master_clas/pravila_reportazhu_pavela_reshki_navproti_kvartiri_putina_ya_pobachiv_putinsku_ rosiyu/

8 Baley, L. (2012), «Facts about Polish literature of fact» [online: April 9, 2012], available at: http:// litakcent.com/2012/04/09/fakty-polskoji-literatury-faktu/

9 Knyazevich, O., (2011), «Mariusz Szczygieł - Reportage:the story that has actually took place and needsunderstanding», [online: December 11, 2011], available at: https://ucu.edu.ua/news/mariushschyhel-reportazh-istoriya-yaka-dijsno-vidbulasya-i-potrebuje-osmyslennya-zik/ 
диною, адже людська доля - найкраща ілюстрація того, що відбувається навколо. Польській школі репортажу притаманне використання декількох героїв у тексті з акцентами на кількох основних історіях. Здебільшого репортери ніби вплітають героїв у текст: пряму мову журналісти подають діалогами, ламають конструкцію тексту, заводять та виводять героїв із матеріалу. «У тексті має бути декілька героїв. Найкраще 5-6, якщо, звісно, ви не пишете матеріал тільки про одну людину. Завжди треба ставити собі за мету знаходити потрібних героїв» ${ }^{10}$.

Аби картина виглядала цілісною, журналісти об’єднують героїв або спільною проблемою, або ідеєю. Іноді об'єднують таких героїв не лише в один репортаж чи розділ, а видають книги з історій, створюючи в такий спосіб неперервність однієї великої історії, яка своєю чергою складається із маленьких історій багатьох героїв. Важливо наголосити, що іноді героєм стає не конкретна людина, а ціла установа, система, спільнота чи явище. До прикладу, вже у згаданій книзі «Біла гарячка» Яцека Гуго-Бадера центральним репортажем є розповідь про долю оленярської бригади евенків та про іiі головного ворога, який знищив цю бригаду вщент, - білу гарячку. Іноді репортери самі стають героями своїх матеріалів: про «ліс речей» пише Капусцінський в яскравому прикладі надзвичайно популярного репортажу, де героями $\epsilon$ журналісти. Експеримент подружжя репортерів Ізабейли Мейзи та Вітольда Шабловського, які написали книгу репортажів про Польську Народну Республіку «Наша маленька ПНР», де самі відтворили життя, побут і реалії життя поляків у 80-х роках ХХ століття. Дослідниця Н. Малетич називає це «репортажем-перевтіленням» ${ }^{11}$.

Подружжя не користувалось сучасними технічними засобами зв'язку та повсякденного життя, аби порівняти, чим сучасні поляки відрізняються від тодішніх. «Ми одягалися, як люди в часи ПНР. Вітольд забрав з села куртку, яку вже давно не носив, а я зробила собі хімію. Люди часто приймали нас за бомжів. Якось наш сусід навіть приніс одяг для дитини. Він не знав, що ми займаємося цим проектом»12, пригадує репортерка.

Важливо підкреслити, що іноді героями стають і мертві люди, найкраще цей репортажний прийом проілюструє феноменальна репортажна книга Войцеха Тохмана «Ти наче камінь їла», де журналіст розповідає про покалічені через війну в Боснії та Герцеговині 1992-1995 років долі людей, через живих світків зазираючи до історій тих, хто загинув. «Я не пишу про могили. Я розповідаю про живих людей, які стоять над смердючими дірками в землі. Про те, що вони носять в собі, ось що для мене важливо» ${ }^{13}$.

У польському літературному репортажі зрозуміти людину - це один із основних канонів жанру. Про це неодноразово нагадує один із найвідоміших репортерів Польщі Вітольд Шабловський: «Ідеальний репортаж, незалежно від того, в якій країні

${ }^{10}$ Shcheglova, J., (2012), Report as a translation from reality, [online: March 22, 2012], available at: https://zik.ua/news/2012/03/22/reportazh yak pereklad z realnosti 340279

${ }^{11}$ Maletich, N., (2013), «Izabela Meyza: I do not believe in the fact that life «will be transferred» on Facebook», [online: October 10, 2013], available at: http://itakcent.com/2013/10/15/izabela-mejza-nevirju-v-te-scho-zhyttja-perenesetsja-na-facebook/

12 Abis, T., (2013), «Izabela Meyza Time Machine», [online: September 17, 2013], available at: https:// varianty.lviv.ua/14237-mashyna-chasu-izabely-

${ }_{13}$ Book Institute Poland, available at: http://instytutksiazki.pl/literatura,8,indeks-autorow,26,wojciechtochman,215.html?filter $=\mathrm{T}$ 
він написаний, має бути якомога ближчий до людей. Немає нічого простішого, ніж зробити репортаж про якогось відомого політика чи поп-зірку. Про них легко писати, але це не ті люди, які живуть прототипним життям країни. Репортаж повинен передавати пульс країни, у якій його пишуть. У ньому має відчуватися випита разом горілка, розділена їжа, викурені разом цигарки, проведений разом час» ${ }^{14}$.

А для того, щоб описати життя цих людей, потрібно насамперед бути одним iз них. На цьому акцентував Ів Аньєс, провідний представник французької школи репортажу, редактор газети «Le Monde»: «Зазвичай треба дати себе прийняти, або навіть зробити так, щоб про вас забули <... . Довести цю поведінку до максиму - це «занурення» ${ }^{15}$. Репортер іноді стає для героїв другом, братом, однодумцем, для цього журналіст потребує підготовки та певних професійних навичок, які допоможуть йому «розповісти» історію.

\section{Комунікативна стратегія роботи з героями у польському репортажеві.}

У польській літературі факту саме робота з героями є визначальною особливістю, адже історії, які віднаходять репортери, ілюструють не лише життя конкретної людини, а й цілої нації чи навіть країни: «.<... . . .героєм може бути місто чи країна, де відбуваються події. Але що вужчий ваш фокус під час написання, то краще» ${ }^{16}$. Варто зазначити, що кожен репортер послуговується своєю унікальною комунікативною стратегію роботи з героями репортажів під час його написання (безпосередньої роботи «у полі»), проте варто детально розкрити два найважливіші пункти, які є ключовими для роботи журналіста, від яких залежить якість, цікавість, глибина тексту.

Репортер - досконалий інтервюер

Основою роботи репортера є спілкування із своїми героями, перебуваючи на місці події чи історії, де журналісти проводять інтерв’ю. Перше завдання журналіста у роботі з героєм, переконати його у важливості його історії. «Справа журналіста переконати людину, що варто порозмовляти» ${ }^{17}$.

Після того, як герой вже «налаштований» на спілкування, журналіст може проводити інтерв'ю. Здебільшого репортери уникають зайвого офіціозу, а розпитують героя, зважаючи на динаміку розвитку спілкування. Тут важливо все: від того, у якому настрої герой, до того, чи вдале місце для розмови. «Хороший репортажист має бути антропологом, тому що ця наука дає змогу вивчати людину в усіх сферах» ${ }^{18}$.

Пильний репортер уникає штампів у запитаннях і готується до зустрічі із героєм. Поставити правильні, точні, атмосферні запитання, а також відкрити свого

${ }^{14}$ Baley, L., (2013), «What should the perfect Ukrainian reportage look like?», [online: October 23, 2013], available at: http://itakcent.com/2013/10/23/jakym-maje-buty-idealnyj-ukrajinskyj-reportazh/

${ }^{15}$ Agnes, Y., (2013), Journalist's Handbook: Let's write for newspapers, Kyiv, Publishing House «KyivMohyla Academy», vol. 544, p. 308.

${ }^{16}$ Kushnir, Y., (2015), «Igor Miecik Reporting Rules: "You will not be able to think out better than God has done» [online: November 2, 2015], available at: http://ms.detector.media/mediaprosvita/master clas/pravila reportazhu iora mechika vi ne zmozhete vigadati krasche nizh vigadav bog/

${ }^{17}$ Maletich, N., (2012), «Jacek Hugo-Bader: There can be no better material for a journalist than a decay of a state», [online: April 1, 2012], available at: https://zaxid.net/yatsek guobader dlya zhurnalista ne mozhe buti krashhogo materialu nizh zanepad derzhavi n1251576

18 Tkachyshyn, P. (2016), «Reporter Witold Szabłowski: Poland is tired of learning freedom, it has now reared ontoits hind legs and began to dance», [online: October 1, 2016], available at: http:// ms.detector.media/mediaprosvita/master clas/reportazhist vitold shablovskiy polscha vtomilas vid_navchannya_svobodi_vona_zaraz_stala_na_zadni_lapi_y_pochala_tantsyuvati/ 
героя, - ось ключове завдання репортера. Здебільшого під час розмови журналісти послуговуються відритими запитаннями, намагаються провадити розмову так, аби «вивести» героя із зони комфорту. Кожен репортер зважає на індивідуальні обставини розмови, при цьому послуговується чотирма відомими журналістськими прийомами:

- У розмові переходити від налаштовуючих запитань до конкретних;

- Починати розмову одразу із суті;

- Чергувати запитання загальні, конкретні і гострі;

- Розмовляти «плавно» і неочікувано для героя ставити гостре запитання.

Польські репортажисти, які працюють із соціальними темами, радять дотримуватися журналістської етики і перефразовувати болючі запитання. Ось Маріуш Щигел та Войцех Тохман наголошують на тому, що «у згвалтованої в Боснії жінки не можна запитувати, як виглядав гвалтівник», «У матері, дітей якої вбито на війні, не треба запитувати про їхній день народження. Але можна і треба питати про все інше: якими діти були, чим бавились і як навчалися. Мертві діти мають бути майже присутніми між репортером та матір'ю, яка їх оплакує. Треба їй нагадати. Треба так розмовляти, аби вони там були. I тоді матір буде про них розповідати зі своєрідною втіхою» ${ }^{19}$.

Те саме стосується журналістського посвідчення, репортери намагаються «влитись» у середовище, не обманюючи свого героя, проте й не відлякуючи його від себе: «Для репортажу потрібна правда, а вона може змінюватись, коли людина дізнається, що ти журналіст. Вона може не сказати тобі того, що скаже своїм друзям і сусідам. Не треба лякати людей журналістським посвідченням» ${ }^{20}$.

Життя «зсередини» або метод «live-in»

Для кращого розуміння атмосфери та героїв тексту, польські репортери часто перебувають на місці репортажу, використовуючи відомий репортерський метод «live-in», або ж «життя зсередини». Метод передбачає, що журналіст їде до своїх героїв і проживає з ними декілька днів, спостерігає за їхнім життям і поведінкою, показує їхнє реальне повсякденне життя. Такий метод - дієвий засіб грунтовного пізнання явища і один із методів збору інформації «нового журналізму», розгалуженням якого є й польська література факту. Прийом live-in дає змогу глибинного спостереження та відкриває перспективи для журналістських спостережень. Найчастіше польські репортери у текстах живуть таким самим життям, як і їхні герої, або намагаються максимально «увійти» в життя героїв.

До прикладу Яцек Гуго-Бадер для подорожей Росією придбав собі «УАЗик», аби не виділятися, «У колгоспі «Мечта Ильича» я на своєму «Ауді Q7» видавався б інопланетянином» ${ }^{21}$. Свою комунікативну стратегію він називає «методом бродячого собаки», що означає максимальне влиття у реальне життя героїв. Чи ось Павел

\footnotetext{
${ }^{19}$ Szczygiel, M., Tochman, W., (2011) «A Reportage - a story about the things that actually happened», [December 27, 2011], available at: http://osvita.mediasapiens.ua/material/4200

${ }^{20}$ Kovalenko, O., Golovko, K., (2014), Reporting rules by Pawel Reszka: "In front of Putin's apartment I saw Putin's Russia"», [online: October 28, 2014], available at: https://ms.detector.media/mediaprosvita/ master_clas/pravila_reportazhu_pavela_reshki_navproti_kvartiri_putina_ya_pobachiv_putinsku_ rosiyu/

${ }^{21}$ Hugo-Bader, J., (2012), «White Fever: A Journey to the Frozen Heart of Siberia», Kyiv, Tempora, vol. 338., pp. 8 .
} 
Решка, який у час Революції Гідності в Україні жив на Позняках в Києві, щоб зрозуміти, де закінчується Майдан і починається рутинне життя. Розглянути подію чи історію з іншого боку, а не споглядати зверху. «Коли ти йдеш до магазину купити щось до сніданку, говориш там із тіткою за прилавком, ти входиш у справжнє життя міста й країни. Тоді ти - звичайна людина, а не журналіст». Для автора надзвичайно важливо бачити на власні очі те, що відбувається, чути діалоги, спостерігати за жестами та мімікою героїв, особисто відчути навколишнє середовище, тому ключовою особливістю роботи з героями $є$ використання у тексті їхньої «живої» мови, діалогів. Польські репортери намагаються подавати діалоги такими, якими вони були у реальному житті, використовуючи слова, які вживали їхні герої. Правдиво і без обробок. Іноді для автентичного звучання ситуації репортер використовує лексику, яка відображає середовище, у якому відбувається подія.

Все це допомагає читачеві перенестись у ситуацію репортажу, відчути героя і навіть запам'ятати його особливості. Маріуш Щигел акцентує на використанні саме «людської» мови у репортажах: «Часто цікаві факти і звороти, які чую від людей, я використовую у своїх репортажах. Ви самі їх не придумаєте, тому беріть їх і записуйте. Потім ви обов'язково їх використаєте у тексті» ${ }^{22}$.

Ось, до прикладу, В. Шабловський у репортажі «Корабельна катастрофа» цитує героя Махмута, мова якого пересипана нецензурними словами,репортер робить це для того, щоб передати атмосферу і складність ситуації, адже його герой кричить ці слова до свого друга наркомана: «Ти обдовбався! Мать твою! Знов ти обдовбався! кричить Махмут ${ }^{23}$. Саме за допомогою автентичних діалогів, текст передає справжні емоції, атмосферу ситуації, у якій живуть герої.

\section{Висновки}

Отже однією з ключових особливостей польського репортажу є присутність у текстах унікальних, документальних, рельєфних героїв, які найкраще ілюструють подію, історію, тему, яку обрав журналіст. Здебільшого польські репортери розповідають історії звичайних («епічних») людей (живих чи мертвих, як у випадку із репортажами В. Тохмана), із незвичайними, метафоричними історіями. Часто в одному тексті репортажу є одразу декілька героїв, для кращої ілюстрації теми. Проте центральний персонаж все-таки переважає своєю «присутністю» у тексті. Здебільшого репортери пов’язують репортажі у цикли, блоки, чи видають книги. Створюючи ефект, коли одна історія плавно перетікає у іншу, чергують героїв у довільному порядку, експериментуючи із структурою текстів. Саме тому польська література факту так часто з'являється у книжковому форматі.

Під час безпосередньої роботи із героєм журналісти послуговуються індивідуальними комунікативними стратегіями. Передовсім репортер повинен володіти досконалими навичками інтерв’юера. Для кращого написання тексту польські репортери послуговуються методом «нового журналізму» - «live-in», або «життя зсередини», чи своїми винятковими методами (Я. Гуго-Бадер «метод бродячого собаки»)». За допомогою цих методів медійники перебувають у реальному житті героя, вливаються у середовище репортажу, спілкуються і живуть з героєм в одному про-

${ }^{22}$ Salo, I., (2013), Reporting makes it possible for a person to look into the windows of neighbors - Mariusz Szchigel, [online:April 8, 2013], available at: http://journalism.ucu.edu.ua/program-highlights/450/

${ }^{23}$ Szablowski, W., (2012), «The Assassin from Apricot City», Kyiv, Tempora, vol. 257, pp. 179. 
сторі. Це допомагає репортерам передати «живу» атмосферу репортажу, деталі та, безумовно, діалоги героїв і один з одним, і з журналістом, що робить текст унікальним та близьким читачеві.

\section{REFERENCES}

1. Abis, T., (2013), «Izabela Meyza Time Machine», [online: September 17, 2013], available at: https://varianty.lviv.ua/14237-mashyna-chasu-izabely-

2. Agnes, Y., (2013), Journalist's Handbook: Let's write for newspapers, Kyiv, Publishing House "Kyiv-Mohyla Academy", vol. 544.

3. Babenko, V., (2013), Narrative text in the news format, [online], available at: http:// er.ucu.edu.ua/handle/1/711

4. Baley, L. (2012), «Facts about Polish literature of fact» [online: April 9, 2012], available at: http://litakcent.com/2012/04/09/fakty-polskoji-literatury-faktu/

5. Baley, L., (2012), A journey through the depths of souls: the author of «White Fever» on the specificfeatures of the post-Soviet space, [online: May 8, 2012], available at: http:// tyzhden.ua/Culture/43125?attempt $=1$

6. Baley, L., (2013), What should the perfect Ukrainian reportage look like?, [online: October 23, 2013], available at: http://litakcent.com/2013/10/23/jakym-maje-buty-idealnyjukrajinskyj-reportazh/

7. Bartosz, M., (2010), Małgorzata Szejnert, [online: October, 2010], available at: https:// culture.pl/ru/artist/malgozhata-sheynert

8. Bernacki, M., Pawlus, M., (1999), «Słownik gatunków literackich», Park, vol. 611.

9. Book Institute Poland., available at: http://instytutksiazki.pl/literatura,8,indeksautorow,26,wojciech-tochman,215.html?filter=T

10. Hugo-Bader, J., (2012), «White Fever: A Journey to the Frozen Heart of Siberia», Kyiv, Tempora, vol. 338 .

11. Knyazevich, O., (2011), Mariusz Szczygieł - Reportage: the story that has actually took place and needsunderstanding, [online: December 11, 2011], available at: https://ucu. edu.ua/news/mariush-schyhel-reportazh-istoriya-yaka-dijsno-vidbulasya-i-potrebujeosmyslennya-zik/

12. Kostovskaya, A., (2016), Witold Shablovsky: I want «Righteous Traitors. Neighbors from Volyn» to become a bridge between the Poles and the Ukrainians, [online: December 16, 2016], available at: http://archive.chytomo.com/interview/vitold-shablovskijxochu-shhob-pravedni-zradniki-susidi-z-volini-stala-mostom-mizh-polyakami-jukraiincyami

13. Kovalenko, O., Golovko, K., (2014), Reporting rules by Pawel Reszka: "In front of Putin's apartment I saw Putin's Russia"», [online: October 28, 2014], available at: https:// ms.detector.media/mediaprosvita/master_clas/pravila_reportazhu_pavela_reshki navproti kvartiri putina ya pobachiv putinsku rosiyu/

14. Kushnir, Y., (2015), Igor Miecik Reporting Rules: "You will not be able to think out better than God has done" [online:November 2, 2015], available at: http://ms.detector.media/ mediaprosvita/master_clas/pravila_reportazhu_iora_mechika_vi_ne_zmozhete vigadati_krasche_nizh_vigadav_bog/ 
15. Maletich, N., (2013), Izabela Meyza: I do not believe in the fact that life «will be transferred» on Facebook, [online: October 10, 2013], available at: http://litakcent. com/2013/10/15/izabela-mejza-ne-virju-v-te-scho-zhyttja-perenesetsja-na-facebook/

16. Maletich, N., (2012), Jacek Hugo-Bader: There can be no better material for a journalist than a decay of a state, [online: April 1, 2012], available at: https://zaxid.net/yatsek guobader_dlya_zhurnalista_ne_mozhe_buti_krashhogo_materialu_nizh_zanepad derzhavi n1251576

17. Salo, I., (2013), Reporting makes it possible for a person to look into the windows of neighbors - Mariusz Szchigel, [online: April 8, 2013], available at: http://journalism.ucu. edu.ua/program-highlights/450/

18. Shcheglova, J., (2012), Report as a translation from reality, [online: March 22, 2012], available at: https://zik.ua/news/2012/03/22/reportazh_yak_pereklad_z realnosti 340279

19. Szablowski, W., (2012), «The Assassin from Apricot City», Kyiv, Tempora, vol. 257.

20. Szczygiel, M., Tochman, W., (2011) A Reportage - a story about the things that actually happened, [December 27, 2011], available at: http://osvita.mediasapiens.ua/ material $/ 4200 \backslash$

21. Tkachyshyn, P., (2016), Reporter Witold Szabłowski: Poland is tired of learning freedom, it has now reared ontoits hind legs and began to dance, [online: October 1, 2016], available at: http://ms.detector.media/mediaprosvita/master clas/reportazhist vitold_shablovskiy_polscha_vtomilas_vid_navchannya_svobodi_vona_zaraz_stala_ na_zadni_lapi_y_pochala_tantsyuvati/ 


\title{
POLISH SCHOOL OF THE LITERATURE OF FACT: CHARACTERS OF THE REPORTAGES AS THE REFLECTION OF REALITY
}

\author{
Khrystyna Golovko \\ Ivan Franko National University of Lviv, \\ Generala Chuprynky Str. 49, 79044, Lviv, Ukraine \\ e-mail: khristinagolovko@gmail.com \\ https://orcid.org/0000-0001-7603-984X
}

The article analyzes the key feature of Polish school of the literature of fact, specifically the journalistic work with the heroes of the materials that are the basis of the reportorial text. There are analyzed peculiarities of characters selection typical for Polish reportage. Further the article explores the specific features of communicative strategies of Polish reporters, reportorialtechnique. For a better understanding there are given thevisual examples from reportorial texts. The main task for a reporter at the scene where the reportage takes place is to find proper characters and convince them of the importance of their story. Mostly, Polish reporters narrates about ordinary («epic») people with unusual, metaphorical stories. Often one reportage text combines several heroes at once for a better illustration of the theme. However, the central character still prevails with his/her «presence» in the text. For the most part, journalists unite reportages into cycles, blocksor publish books. The journalists of the literature of fact work with the heroes of reports, adhering to the journalistic standards and the code of ethics, they consider the traditions and basics of Polish reportage school, where the story of the character is the core of the text. In order to write a text in the best way Polish reporters use the method of «new journalism» - «live-in» or «life from withwin or their exceptional methods (Jacek Hugo-Bader «the method of the lost dog»), due to which they are staying ina real life of a character, blend into the environment of reporting, communicate and live with a character in one space. It helps a reporter to represent the «live» atmosphere of reportage, details and, of course, dialogues both between characters and the reporter, which makes the text unique and close to a reader.

Key words: New Journalism, Polish literature of fact, communicative strategy, «live-in» method. 